\title{
EARNING PERSISTENCE ON FIRM TAX DIFFERENCES AND FAMILY OWNERSHIP
}

\author{
Synthia Madyakusumawati ${ }^{1}$ \\ Unika Atma Jaya \\ synthia.madya@atmajaya.ac.id
}

\author{
Hyashinta Dyah $\mathbf{P}^{2}$ \\ Unika Atma Jaya \\ hyasshinta.dyah@atmajaya.ac.id
}

Diterima 24 April 2020

Disetujui 2 Juni 2020

\begin{abstract}
Prior research find evidence consistent with the hypothesis that future earnings influenced by difference between accounting and fiscal earnings (book tax differences). Many investors forming expectations of future earnings information derived from the difference between fiscal and commercial earnings, there were some investors would satisfied to see small differences between fiscal and commercial earnings, otherwise have the opposite view. This study aim to investigate how book-tax difference and family ownership play a role in the persistence of earnings. The authors using a sample 692 firm years of Indonesian listed companies within 2011-2016, they estimate cross-sectional regressions of the proxy for booktax differences and family ownership on earning persistence. The study found that current pretax earnings can predict future earnings and also firm years with large book-tax difference have less earnings persistence than firm years with small book tax difference. Further, this study found no evidence that family ownership have significant role in persistence of earnings.
\end{abstract}

Keywords: Earning Persistence, Future earnings, Pre-tax earnings, Book tax difference, Family Ownership.

\section{INTRODUCTION}

All of us will agree that earnings is the most popular from the whole financial report. Earnings always be favourite term to be discuss for everyone, even they are not economist. This condition is consistent with signalling theory, where the company will give signal (earnings) to the stakeholder in order to achieve their goals. As a signal, earnings should have several qualitative characteristics, which mentioned in Standar Akuntansi Keuangan (SAK) 2017. Accounting earnings is used to reflect fundamental performance. It is important to aligned accounting measures with the objects they reflect (Steen, 2016). We could identify companies which likely to show increasing or decreasing future earnings by studying the components of their current earnings. Quality of earnings is defined as relevant information level that a firm can provide financial statement users in their decision-making (Dechow, Ge, \& Schrand, 2010). High quality of earnings represents the reliability and relevance of the accounting information. Earnings called relevance when it has predictive value, which is when it persistence.

We investigate the role of book-tax differences and family ownership in indicating the persistence of earnings. Financial accounting texts claims the difference between pre-tax book income and taxable income can provide information about current earnings. The underlying 
reason is less discretion allowed in calculation of taxable income. Potential cost and benefit from small differences between fiscal and accounting earnings have been debated in Indonesia. Proponents suggest that small book-tax difference will simultaneously reduce aggressive financial reporting thereby improving earnings quality and increasing tax compliance (Atwood, Drake, \& Myers, 2010). Opponents argue that the information required by financial statement users is different from that required by tax authorities, there for small book tax differences will lower earnings quality whereas vice versa large book tax differences will enhance quality of earning (Hanlon, Laplante, \& Shevlin, 2005; Hanlon, Maydew, \& Shevlin, 2008).

According to (Jensen, 2000), ownership structure is significant in determining firms' objectives, shareholders wealth and the disciplined of manager. Both managers and shareholders should have a single objective of maximizing firm value. The family controlled firm or family ownership is the most common form of business organization in the world, and even more popular in Indonesia and other Asia countries. The study of The Jakarta Consulting Group (Hariyanto \& Juniarti, 2014) found that 85\% Indonesian company's are family controlled.

Whether the family firm is an effective business models remains an issue of ambiguity. Some studies argue that family ownership is associated with lower abnormal accruals, greater earnings informativeness and less persistence of transitory loss components in earnings (Wang, 2006). Higher family ownership will result in lowering earning persistence. The company with family ownership in group firms, was both associated with lower earnings quality (Tessema, Kim, \& Dandu, 2018). On the other hand, some studies found that family ownership will reduce agency problem, resulting efficient earnings management and increasing earnings persistence (Siregar \& Utama, 2008)

Our result indicate that for firm-years with large book-tax difference have less persistence for one-year-ahead earnings than firm years with small book tax difference. This consistent for the large positive and the negative one. This evidence is consistent with the proponent's conjecture that large book-tax differences will resulting lower earnings persistence. In the other hand, my result could not found evidence that family ownership has impact in persistence of earnings. This result indicate that the persistence of earnings will not differ between company owned by family or not.

The remainder of this paper is organized as follow. Section 2 discusses prior literature review and develops our hypotheses. Section 3 describes our research design and sample selection. Section 4 describes descriptive statistics, and test result. Section 5 concludes the paper.

\section{LITERATURE REVIEW}

\subsection{Book-Tax Differences}

Book-Tax Differences defined as discrepancy between accounting earnings and fiscal earnings. Management calculates corporate income tax for two purposes each year, the first is for financial reporting purposes under SAK and the second is in accordance with the Direktorat Jendral Pajak to determine corporate income tax liabilities. For most corporations, taxable income is calculate based on accrual basis rather than cash basis. The difference method in calculating income tax expense will result in difference number of tax expense. Differences between accounting income and taxable income can be large. Some differences, known as permanent differences and the others known as temporary difference. (Hanlon, Krishna, \& Mill, 2012) stated that these differences give incentives applying to accounting and fiscal earnings have the effect of making each of these earnings measures incrementally informative relative 
to the other, and they present evidence that fiscal earnings is informative even after controlling for accounting income. There are three types of book-tax differences. First, differences in the timing of accrual recognition between book and taxable income which called temporary differences (e.g., bad debt reserve, warranty reserve, depreciation, etc.). Temporary differences present information about the quality of pre-tax accounting accruals. Second, permanent booktax differences, e.g interest revenue, tax penalties, final accounting revenue. Permanent differences denote as pre-tax book and fiscal earnings that never reverse. Permanent differences are not often suspected to be indicators of earnings quality in terms of accruals manipulation due to they are not related to the timing of accrual recognition. The third are book-tax differences that do not affect earnings begore tax, but influence income tax expense account and, thus, only after-tax earnings. Examples include tax accruals such as the contingency reserve and the valuation allowance (Hanlon, Krishna, \& Mill, 2012)

Following (Hanlon, Laplante, \& Shevlin, 2005) exclude permanent difference in this study, because permanent differences are difficult to measure. So, I do not examine the relation between permanent differences and earning persistence.

Differences between accounting income and taxable income can be also small. Small book tax differences simultaneously provides incentives for managers to reduce tax avoidance and to report accounting earnings less aggressively, which will result in improved earnings quality (Desai, 2005; Whitaker, 2006). Higher quality of earnings indicating higher persistence of earnings.

Furthermore the opponents argue that small book tax differences will result in lower quality (or less informative) accounting earnings (Hanlon, Maydew, \& Shevlin, 2008; Hanlon, Laplante, \& Shevlin, 2005). They argue that the information required by taxing authorities differs from that required by investor. The tax system is designed to meet the government's goals of increasing revenue. In contrast, accounting earnings provides information about firm performance and is intended to reduce information asymmetries between management and shareholders. Thus, the accounting system is designed to allow managers flexibility in conveying information to the market (Hanlon, Laplante, \& Shevlin, 2005). As a result of these different goals, opponents argue that small book tax differences will reduce the quality of information available to investors and other financial statement users.

\subsection{Family Ownership}

Families and business company control a high percentage corporations in developed countries. Some of the company relate with one or more other families. This information implies that, in most cases, there are majority shareholder who do the control over the strategic decisions the firm and bear the consequences. Family ownership play an important role in large firms in Indonesia, regarding the relationship between concentrated family ownership and control on the one hand and firm performance on the other hand. Family ownership structure plays an important role on earnings persistence.

Based on agency theory (Jensen, 2000), agency problem arise from separation between de facto ownership and control between corporate insiders (e.g. controlling shareholders) and outsiders (e.g. minority shareholders). Family ownership, how ever represent controlling share holders, while minority share holder represent others (de Sousa \& Galdi, 2016), controlling or concentration might have a negative effect on performance (earning persistence) if majority shareholders take advantage of the opportunity to expropriate minority shareholders. On the other hand, regarding about dimension of family control characteristics, family involvement may have a positive effect on performance if the firm's governance institutions. Contradictory many research found that family firms under perform non family firms, however recent studies 
in Asia conclude a doubt on this conclusion, and even state the active involvement of the family in management responsibilities is positive for the firm (Majluf, 2008)

Studies found that $85 \%$ of Indonesian company is characterized by family business, where most firms have concentrated ownership structures. Therefore, Indonesia company are family controlled. Actually this condition will reduce agency problem type 1 (problem between principal and agent), because there will more engagement between principal and their agent (Astuti, Rahman, \& Sudarno, 2015). Besides, this family ownership will more concerned with the company's going concern due to they have it (Segura \& Formigoni, 2014). Since this principal is more concerned, so they will more controlled the agent too (Ibrahim \& Samad, 2011). So the agent will prepare the efficient earnings management which will increasing the earnings quality (Siregar \& Utama, 2008). Actually this condition is support the stewardship theory, where the agent will act as a steward. As a steward, agent will place higher value on cooperation and trustworthy.

Consistent with prior research in this country, this study also stand in the stewardship theory. This study assume that the earnings management in family ownership will efficient so increasing the earning quality

\subsection{Earning Quality}

Earnings quality is conditional on the decision relevance of the information. The Quality of reported earnings number depends on how informativeness the earning present financial performance (de Sousa \& Galdi, 2016). Studies examining earnings quality in both, book-tax differences and family ownership related, provide mixed evidence. (Hanlon, Laplante, \& Shevlin, 2005) found that firm-years with large book-tax difference have earnings that are less persistent than firm-years with small one. This means that large book-tax difference will reduce earnings quality. This study was opposite with (Atwood, Drake, \& Myers, 2010) (Hanlon, Maydew, \& Shevlin, 2008) where they found that increased in book-tax conformity may reduce earnings quality. It means that large book-tax difference may increase the earnings quality.

Meanwhile, studies related with family ownership and earnings quality also still have no consistent result. Several studies found that higher family ownership will decreasing earnings (Wang, 2006) (Tessema, Kim, \& Dandu, 2018). But Siregar \& Utama (2008) found that higher family ownership will increasing earnings quality.

In our country, SAK has mentioned four qualitative characteristics of financial report, that are: relevance, reliable, comparability, and understandable. In this study, we will discuss more about relevance. Information called relevance if the quality or state of being closely connected or appropriate. In the context of financial report, it would relevance if the financial information could effected the user's decision by evaluating prior event, or predicting future, and also correcting prior evaluation.

There are several requirements related to relevance: 1) feedback value; 2) predictive value; 3) timeliness; and 4) complete. In this study, we will focus on predictive value. Financial information will ha predictive value if they could help user in order to predict future by using prior and current information. So, the financial information should be persistence.

One of the most popular information in the financial report is earnings. Earnings also used widely by company as a signal to their stakeholder that management performed great or not. Higher earnings usually indicate higher management performances. Since earnings commonly used by stakeholder to make decision, so earnings should be persistence. 


\subsection{Hypotheses}

We suggest an increasing of book-tax difference will reduce the earnings persistence. The more differences between accounting income and taxable income indicating that the management perform more tax aggressiveness where lead to decreasing earnings quality. Decreasing quality of earnings indicating lower persistence of earnings. So, the first hypothesis is Large Positive Book-Tax Difference or Large Negative Book-Tax Difference have lower earnings persistence than Small Book-Tax Difference.

Meanwhile, the family ownership expected will lower the agency problem, produce more engagement with the management and more control, where lead to increasing earning quality. Increasing earning quality indicating higher persistence of earnings. So, the next hypothesis is higher family ownership will generate higher earning persistence.

\section{RESEARCH METHODS}

We start with a sample of firm year 2011-2016 from Indonesia Stock Exchange data. Our sample consists of 1037 observation (200 firms), exclude financial services industries. To be included in the final sample, the observation must not have missing variables uses in the regression, a reported financial reporting loss, a negative current tax expense. The reason for these screens is that tax losses can be carried forward and thus become deferred tax assets, changes in which can obscure the effects of "true" book tax difference in the deferred tax expense account. Our final sample consist of 692 observation (174 firms). We partition this sample into three subsamples : LPBTD (Large Positive Book Tax Difference -129 firm years), LNBTD (Large Negative Book tax difference - 98 firm years), and SBTD (small book tax difference - 465 firm years).

\subsection{Research Design}

Prior studies examining book tax differences in the properties of accounting earnings generally do not control for the effect of family ownership structure, (Majluf, 2008; Ibrahim \& Samad, 2011). First, we estimate earning persistence by regression to prove the pre-tax book income current year (PTBI t) can predict future earnings (PTBIt+1 ). Second, we examining whether small book tax differences have higher persistence of future earnings. We estimate whether the persistence of future earnings is lower for firm years with large negative or large positive book tax differences relative to firm years with small book tax differences

\subsubsection{Earnings Persistence}

Test of earnings persistence can be measured by regression pre tax book income current year to pre tax book income one year ahead. We estimate the persistence of pre tax earnings using the following equation :

$$
\text { PTBIt }+1=\alpha 0+\alpha 1 \text { PTBIt }+\varepsilon t+1
$$

Where PTBI is pre tax book income, as in (Hanlon, Laplante, \& Shevlin, 2005), we scale all variable by average total assets to allow for cross sectional comparability.

We use the first equation to reveal the prove of persistence of earnings, that is the pretax book income current year (PTBI t ) can predict future earnings (PTBIt+1). Persistence of earnings proved by a significant value below $\mathrm{p}$-Value 0.05 , therefore PTBIt +1 is considered as a reflection of current earnings, accordingly PTBIt +1 can be used as a predictor for the second equation. 


\subsubsection{The persistence of future earnings is lower for firm years with large ngative or large positive book tax differences relative to firm years with small book tax differences}

We have known there were two point of views about the scale of book tax differences. Some of them agree that small book tax difference overviewed persistence of future earnings, while the other refused this views.

To test whether firm years with large negative (positive) book tax difference have lower earnings persistence, we estimate equation (2)

$$
\begin{aligned}
& \text { PTBIt }+1=\alpha 0+\alpha 1 \text { LNBTDt }+\alpha 2 \text { LPBTDt }+\alpha 3 \text { PTBIt }+\alpha 4 \text { PTBIt } \times \text { LNBTDt } \\
& +\alpha 5 \text { PTBIt x LPBTDt }+\alpha 6 \text { FAMt } x \text { PTBIt }+\varepsilon t+1
\end{aligned}
$$

In equation (2):

PTBIt+1

: Pre-tax earnings next year

LNBTD (large negative book tax difference) : is an indicator variable equal to 1 for firm years

with scaled temporary book tax differences in the lowest quintile of firms in each year, and 0 otherwise

LPBTD (large positive book tax difference) : is an indicator variable equal to 1 for firm years

with scaled temporary book tax differences in the highest quintile of firms in each year, and 0

otherwise

PTBIt : Pre-tax earnings current year

FAMt $\quad$ : Family ownership structure

If firm years having large negative (positive) book tax differences have lower earnings persistence than firm years with small book tax differences, then $\alpha 4<0(\alpha 5<0)$, consistent with hypotheses 2

If family ownership structure with current earnings have impact in predicting future earnings, then $\alpha 6$ will have significant $p$-value $(<0,05)$, consistent with hypotheses 3 


\section{RESULT AND DISCUSSION \\ 4.1.Statistic descriptive}

\begin{tabular}{|c|c|c|c|c|c|}
\hline $\begin{array}{l}\text { in million } \\
\text { Rupiah }\end{array}$ & $\begin{array}{c}\text { Fam (\% } \\
\text { Family } \\
\text { Ownership ) }\end{array}$ & LNBTDr & LPBTDr & $\begin{array}{l}\text { PTBI (t) (in } \\
\text { thousand Rp) }\end{array}$ & $\operatorname{PTBI}(t+1)$ \\
\hline Mean & 45 & 0,186 & 0,142 & $282.506,339$ & $302.245,764$ \\
\hline Median & 57 & - & - & $68.990,748$ & $77.390,431$ \\
\hline Mode & - & - & - & $269.216,864$ & $203.109,149$ \\
\hline $\begin{array}{l}\text { Standard } \\
\text { Deviation }\end{array}$ & 35 & 0,390 & 0,349 & $1.335 .542,756$ & $1.382 .611,199$ \\
\hline Range & 100 & 1,000 & 1,000 & $27.214 .192,894$ & $28.637 .276,742$ \\
\hline Minimum & - & - & - & $-65.192,894$ & $-24.276,742$ \\
\hline Maximum & 100 & 1,000 & 1,000 & $27.149 .000,000$ & $28.613 .000,000$ \\
\hline Count & 692 & 692,000 & 692,000 & 692,000 & 692,000 \\
\hline
\end{tabular}

Statistic descriptive (continued)

\begin{tabular}{|c|c|c|c|}
\hline $\begin{array}{l}\text { in million } \\
\text { Rupiah }\end{array}$ & PTBI_X_FAM & PTBI_X_LN & $P T B I \_X \_L P$ \\
\hline Mean & 10.792.370,031 & $76.431,766$ & $102.983,334$ \\
\hline Median & $1.584 .674,524$ & - & \\
\hline Mode & - & - & - \\
\hline $\begin{array}{l}\text { Standard } \\
\text { Deviation }\end{array}$ & $63.445 .564,653$ & $772.183,315$ & $1.086 .218,340$ \\
\hline Range & $1.578 .810 .135,098$ & $17.076 .639,894$ & $27.149 .000,000$ \\
\hline Minimum & $-5.251 .287,598$ & $-65.192,894$ & - \\
\hline Maximum & $1.573 .558 .847,500$ & $17.011 .447,000$ & $27.149 .000,000$ \\
\hline Count & 692,000 & 692,000 & 692,000 \\
\hline
\end{tabular}

The highest percentage for family ownership structure is 100\% (BALI 2012, BALI 2013, AGII 2012, AGII 2013, IMPC 2013, WTON 2013) whereas the minimum is $0 \%$. On Average, the observation have $45 \%$ family ownership structure in their equity. This number provides a general overview about ownership structure in Indonesia where the average of the company's ownership structure is owned by families.

As mentioned above we partition this sample into three sub samples: LPBTD (129 firm years), LNBTD (98 firm years), and small book tax difference (465 firm years). Maximum of PTBIt is 27.149 trillion (TLKM 2013) and the minimum of PTBIt is -65.192 mio (NIKL 2015) 


\subsection{Results from tests of earnings persistence and the association between earnings}

Table 2. Test of first hypotheses

Dependent Variable: PTBI_T1

Method: Least Squares

Date: 01/15/19 Time: 20:39

Sample: 1692

Included observations: 692

\begin{tabular}{|c|c|c|c|c|}
\hline Variable & Coefficient & Std. Error & $\mathrm{t}-$ Statistic & Prob. \\
\hline $\mathrm{C}$ & 10029.28 & 2160.479 & 4.642157 & 0.0000 \\
\hline PTBI_T0 & 1.034406 & 0.001584 & 653.1350 & 0.0000 \\
\hline R-squared & 0.998385 & Mean dependent var & & 302253.2 \\
\hline $\begin{array}{l}\text { Adjusted R- } \\
\text { squared }\end{array}$ & 0.998383 & S.D. dependent var & & 1382610 \\
\hline S.E. of regression & 55601.28 & Akaike info criterion & & 24.69269 \\
\hline Sum squared & 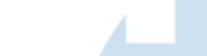 & & & \\
\hline resid & $2.13 E+12$ & Schwarz criterion & & 24.70581 \\
\hline Log likelihood & -8541.669 & Hannan-Quinn criter. & & 24.69776 \\
\hline F-statistic & 426585.3 & Durbin-Watson stat & & 1.750981 \\
\hline $\operatorname{Prob}($ F-statistic) & 0.000000 & & & \\
\hline
\end{tabular}

Table 2 presents the result from hypotheses 1 . We use the first equation to reveal the prove of persistence of earnings, that is the pre-tax book income current year (PTBI $t$ ) can predict future earnings (PTBIt+1 ). p-value in table 2 indicates that firm years in our sample have consistent results with previous findings in (Hanlon, Laplante, \& Shevlin, 2005; Subekti, Wijayanti, \& Rahmawati, 2008; Eka \& Dwi, 2010).

Table 3 presents the result from hypotheses 2 , it reveals that firm years with large book tax difference have lower persistence in pre-tax earnings than firm years with small book tax differences. Firm years with large negative and large positive book tax differences have significantly less persistence of earnings than firm years with small book tax differences that is $\boldsymbol{\alpha}_{4}-0.093 \boldsymbol{\alpha}_{5}-0.032$, two tailed p-values of 0,00001 consistent with the alternate hypotheses stated in $\mathrm{H} 2$, while $\boldsymbol{\alpha}_{\mathbf{6}}$ family ownership have no significance influence to earning persistence. Our sample also have consistent results with previous findings in (Hanlon, Laplante, \& Shevlin, 2005) (Hanlon, Maydew, \& Shevlin, An unintended consequence of book-tax conformity: a loss of earnings informativeness, 2008) (Eka \& Dwi, 2010) 
Table 3 Test of second hypotheses

Dependent Variable: PTBI_T1

Method: Least Squares

Date: 01/15/19 Time: 20:45

Sample: 1692

Included observations: 692

White heteroskedasticity-consistent standard errors \& covariance

\begin{tabular}{crlll}
\hline \hline Variable & Coefficient & Std. Error & t-Statistic & Prob. \\
\hline \hline C & 3848.791 & 2411.226 & 1.596197 & 0.1109 \\
PTBI_T0 & 1.085696 & 0.007351 & 147.6970 & 0.0000 \\
LNBTD & 5054.770 & 3909.204 & 1.293043 & 0.1964 \\
LPBTD & 2887.864 & 5187.627 & 0.556683 & 0.5779 \\
FAM & 20.59441 & 40.06756 & 0.513992 & 0.6074 \\
PTBI_X_LN & $\mathbf{- 0 . 0 9 2 2 6 9}$ & $\mathbf{0 . 0 0 7 7 7 9}$ & $\mathbf{- 1 1 . 8 6 1 6 7}$ & $\mathbf{0 . 0 0 0 0}$ \\
PTBI_X_LP & $\mathbf{- 0 . 0 3 2 2 3 0}$ & $\mathbf{0 . 0 0 7 3 7 9}$ & $\mathbf{- 4 . 3 6 8 0 0 7}$ & $\mathbf{0 . 0 0 0 0}$ \\
PTBI_X_FAM & -0.001760 & 0.004410 & -0.399199 & 0.6899 \\
\hline \hline R-squared & 0.999241 & Mean dependent var & 302253.2 \\
Adjusted R-squared & 0.999233 & S.D. dependent var & 1382610. \\
S.E. of regression & 38288.37 & Akaike info criterion & 23.95517 \\
Sum squared resid & $1.00 E+12$ & Schwarz criterion & 24.00765 \\
Log likelihood & -8280.490 & Hannan-Quinn criter. & 23.97547 \\
F-statistic & 128622.2 & Durbin-Watson stat & 1.856501 \\
Prob(F-statistic) & 0.000000 & & & \\
\hline \hline
\end{tabular}

Table 4 (Robustness Test : exclude family ownerhip variable)

Dependent Variable: PTBI_T1

Method: Least Squares

Date: 01/27/19 Time: 13:53

Sample: 1692

Included observations: 692

White heteroskedasticity-consistent standard errors \& covariance

\begin{tabular}{crrrr}
\hline \hline Variable & Coefficient & Std. Error & t-Statistic & Prob. \\
\hline \hline C & 4794.102 & 1601.238 & 2.993998 & 0.0029 \\
PTBI_T0 & 1.085009 & 0.007285 & 148.9352 & 0.0000 \\
LNBTD & 5062.617 & 3869.503 & 1.308338 & 0.1912 \\
LPBTD & 2385.841 & 5081.504 & 0.469515 & 0.6389 \\
PTBI_X_LN & $\mathbf{- 0 . 0 9 2 7 3 2}$ & $\mathbf{0 . 0 0 7 3 8 6}$ & $\mathbf{- 1 2 . 5 5 5 9 1}$ & $\mathbf{0 . 0 0 0 0}$ \\
PTBI_X_LP & $\mathbf{- 0 . 0 3 1 6 0 1}$ & $\mathbf{0 . 0 0 7 3 0 1}$ & $\mathbf{- 4 . 3 2 8 2 5 6}$ & $\mathbf{0 . 0 0 0 0}$ \\
\hline \hline R-squared & 0.999240 & Mean dependent var & 302253.2 \\
Adjusted R-squared & 0.999235 & S.D. dependent var & 1382610.
\end{tabular}




\begin{tabular}{lrll} 
S.E. of regression & 38242.01 & Akaike info criterion & 23.94989 \\
Sum squared resid & $1.00 \mathrm{E}+12$ & Schwarz criterion & 23.98925 \\
Log likelihood & -8280.662 & Hannan-Quinn criter. & 23.96511 \\
F-statistic & 180507.8 & Durbin-Watson stat & 1.856727 \\
Prob(F-statistic) & 0.000000 & & \\
\hline \hline
\end{tabular}

Table 4, We exclude family ownership variable to control test whether the large book tax difference still have lower persistence in pre-tax earnings than firm years with small book tax differences. The results consistent with table 3, that is firm years with large negative and large positive book tax differences have significantly less persistence earnings than firm-years with small book tax differences that is $\boldsymbol{\alpha}_{4}-0.093 \boldsymbol{\alpha}_{5}-0.032$, two tailed p-values of 0,00001 consistent with the alternate hypotheses stated in $\mathrm{H} 2$.

\section{CONCLUSION}

The objective of our research is to examine the role of temporary book-tax differences in indicating the persistence of earnings.

We find evidence that firm years with large positive book tax difference have lower earning persistence than firm year with small book tax difference. This result is consistent with common notion that when book income is far in excess of taxable income, earnings have lower quality.

We also find evidence that firm years with large negative book tax difference have lower earning persistence than firm years with small book tax difference. Large negative book-tax differences are associated with accruals that have lower persistence for future earnings. This lower earnings persistence also robust after we exclude family ownership variable in the equation.

We include family ownership structure to examine whether book tax difference moderating with family ownership structure will lower persistence of future earnings. The result indicate family ownership structure moderating with book tax difference have no relation with future earnings.

There are several limitation to this research. First the limited sample size and time period impede generalizing the results to other sample and period of times. Second, the limitation of family ownership structure measurement, future research need to lookup the effect of controlling share holder and entrenchment effects of real family ownership. 


\section{REFERENCES}

Abiot Tessema, Moo Sung Kim, Jagadish Dandu. (August 2018). The impact of ownership structure on earnings quality: the case of South Korea. International Journal of Disclosure and Governance, 15(3), 129-141.

Michelle,Hanlon., Maydew, E., Shevlin, T. (2008). An unintended consequence of book-tax conformity: a loss of earnings informativeness. Journal of Accounting \& Economics , 46, 294-311.

Abdelghany, K. E. (2005). Measuring the quality of earnings. Managerial Auditing Journal, 9(2005), 1001-1015.

Abdelghany, K. E. (2005). Measuring the quality of earnings. Managerial Auditing Journal, 20 No. 9, pp 1001-1015.

Apri Dwi Astuti., Abdul Rahman., Sudarno Sudarno. (2015). Pengaruh Kepemilikan Keluarga terhadap Kinerja Perusahaan dengan Agency Cost Sebagai Variabel Moderating. Jurnal Dinamika Akuntansi, 7(2), 98-108.

Dechow, P., Ge, W., \& Schrand, C. (2010). Understanding earnings quality: A review of the proxies, their determinants and their consequences. Journal of Accounting and Economics 50(2), 344-401. doi:10.1016/j.jacceco.2010.09.001.

Desai, M. (2005). The degradation of reported corporate profits. The Journal of Economic Perspectives, 19, 171-193.

Djamaluddin Subekti., Handayani Tri Wijayanti., Rahmawati Rahmawati. (2008). Analisis Perbedaan Antara Laba Akuntansi dan Laba Fiskal Terhadap Persistensi Laba, Akrual, dan Aliran Kas pada Perusahaan Perbankan yang Terdaftar di Bursa Efek Jakarta. The Indonesia Journal if Accounting Research, 11(1).

Erivelto Fioresi de Sousa., Fernando Caio Galdi. (2016). he Relationship Between Equity Ownership concentration and Earnings Quality Evidence From Brazil . Revista de Administracao , 51, 331-343.

Haslindar Ibrahim., Fazilah Abdul Samad . (February 2011). Corporate Governance Mechanisms and Performance of Public-Listed Family-Ownership in Malaysia. International Journal of Economics and Finance, 3(1), 105-115.

Jensen, M. (2000). A Theory of the Firm: Governance, Residual Claims, and Organizational Forms. Harvard University Press Cambridge.

Lidia Hariyanto., Juniarti. (2014). Pengaruh Family Control, Firm Risk, Firm Size Dan Firm Age Terhadap Profitabilitas Dan Nilai Perusahaan Pada Sektor. BUSINESS ACCOUNTING REVIEW,, VOL. 2, No. 1, 141-150.

Majluf, F. S. (2008). Does family ownership shape performance outcomes? Journal of Business Research, 61, 609-614.

Michelle Hanlon, Gopal V. Krishnan, and Lillian F. Mill. (Spring 2012). Audit Fees and Book-Tax Differences. Journal of the American Taxation Association (JATA) Vol. 34, No. 1, 55-86.

Michelle Hanlon, Laplante, S.K., Shevlin, T. (2005). Evidence on the possible information loss of conforming book income and taxable income. Journal of Law and Economics, 48, 407-442.

Persada Aulia Eka., Martani Dwi. (2010). Analisis Faktor Yang Mempengaruhi Book Tax Gap Dan Pengaruhnya Terhadap Persistensi Laba. Jurnal Akuntansi dan Keuangan Indonesia, 7(2), 205-221. 
Segura, L. C., \& Formigoni, H. (2014). Influence of Control and Family Management in the Indebtedness of Brazilian Open Business: a Quantitative Study. Brazillian Business Review, 11(6), 50.

Segura, L. C., \& Formigoni, H. (2014). Influence of Control and Family Management in the Indebtedness of Brazilian Open Business: a Quantitative Study. Brazillian Business Review, 11(6)(50.).

Steen, H. (2016). Organizational Performance And Earnings Quality: A Quantitative Examination Of The Impact Of Organizational Performance On Earnings Quality. A Dissertation Presented in Partial Fulfillment. Capella University. ProQuest 10130057.

Sylvia Veronica Siregar., Sidharta Utama. (2008). Type of earnings management and the effect of ownership structure, firm size, and corporate-governance practices: Evidence from Indonesia. The International Journal of Accounting, 43(1), 1-27.

T.J. Atwood, Michael S. Drake, Linda A. Myers. (2010). Book-tax conformity, earnings persistence and the association between earnings and future cash flows. Journal of Accounting and Economics, 50, 111-125.

Wang, D. (June 2006). Founding Family Ownership and Earnings Quality. Journal of Accounting Research, 44(3), 619-656.

Whitaker, C. (2006). How to build a bridge: eliminating the book-tax gap. The Tax Lawyer 59.

Whitaker, C. (2006). How to build a bridge: eliminating the book-tax gap. The Tax Lawyer, 59.

\section{Appendix}

\section{a. Normality Test}

View $>$ Residual Diagnostics $>$ Histogram - Normality Test

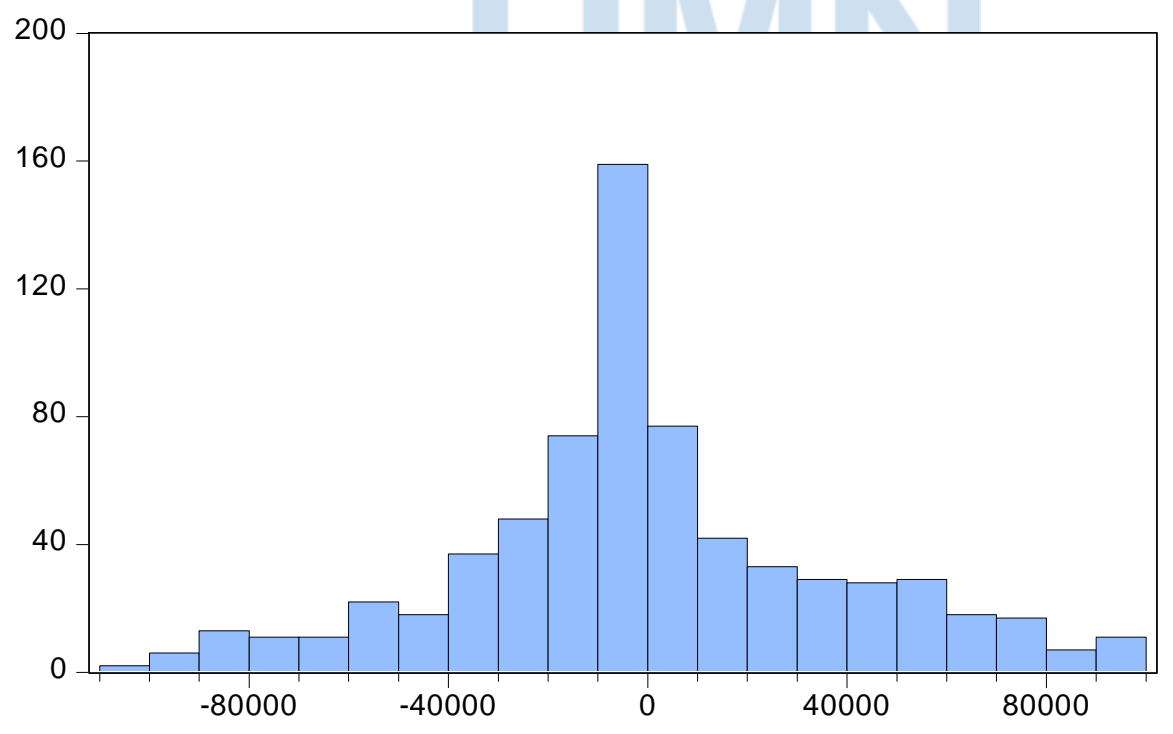

Series: Residuals

Sample 1692

Observations 692

Mean

$5.00 \mathrm{e}-11$

Median $-3937.627$

Maximum

Minimum

99232.04

Std. Dev.

$-107818.1$

Skewness

38103.40

Kurtosis

0.107202

Jarque-Bera 3.805213

Probability 


\section{b. Multicolinearity Test}

Variance Inflation Factors

Date: 01/27/19 Time: 13:32

Sample: 1692

Included observations: 692

\begin{tabular}{cccc}
\hline \hline Variable & $\begin{array}{c}\text { Coefficient } \\
\text { Variance }\end{array}$ & $\begin{array}{c}\text { Uncentered } \\
\text { VIF }\end{array}$ & $\begin{array}{c}\text { Centered } \\
\text { VIF }\end{array}$ \\
\hline \hline C & 2563962. & 1.434150 & NA \\
PTBI_T0 & $5.31 E-05$ & 303.6521 & 297.5147 \\
LNBTD & 14973054 & 1.231629 & 1.050509 \\
LPBTD & 25821681 & 1.301959 & 1.184597 \\
PTBI_X_LN & $5.45 E-05$ & 37.78460 & 37.67177 \\
PTBI_X_LP & $5.33 E-05$ & 266.9670 & 263.4233 \\
\hline \hline
\end{tabular}

\section{c. Heteroskedasticity Test}

Heteroskedasticity Test: White

\begin{tabular}{llll}
\hline \hline F-statistic & 16.12240 & Prob. F $(8,683)$ & 0.0000 \\
Obs*R-squared & 109.9210 & Prob. Chi-Square(8) & 0.0000 \\
Scaled explained SS & 123.8628 & Prob. Chi-Square(8) & 0.0000 \\
\hline \hline
\end{tabular}

Prob. Chi-Square $($ yang kedua $)=0.0000<0.05 \rightarrow$ ada heteroskedastisitas

\section{d. Autocorrelation Test}

Breusch-Godfrey Serial Correlation LM Test:

\begin{tabular}{llll}
\hline \hline F-statistic & 1.875388 & Prob. F $(2,684)$ & 0.1541 \\
Obs*R-squared & 3.773950 & Prob. Chi-Square(2) & 0.1515 \\
\hline \hline
\end{tabular}

\section{e. Linearity Test}

Ramsey RESET Test

Equation: MODEL_2_NO_FAM

Specification: PTBI_T1 C PTBI_TO LNBTD LPBTD PTBI_X_LN PTBI_X_LP

Omitted Variables: Powers of fitted values from 2 to 3

\begin{tabular}{lccc}
\hline \hline & Value & df & Probability \\
\cline { 2 - 4 } F-statistic & 0.683165 & $(2,684)$ & 0.5054 \\
Likelihood ratio & 1.380932 & 2 & 0.5013 \\
\hline \hline
\end{tabular}

